UDC 657.432:336.27:658.884:005.642.2

DOI: $10.15673 /$ fie.v12i3.1813

\section{Stupnytska T.}

Ph.D., Associate Professor

Department of Accounting and Auditing

E-mail: t.stupnitska@gmail.com

ORCID ID: 0000-0002-2517-2795

Volodina 0.

Assistant

Department of Foreign Languages

E-mail: volodinaolenaonaft@gmail.com

ORCID ID: 0000-0003-0552-6733
Antonyuk 0.

Ph.D., Associate Professor

Department of Accounting and Auditing

E-mail: olegantoni@ukr.net

ORCID ID: 0000-0002-9182-4982

Orel A.

Undergraduate

Department of Accounting and Auditing

Odesa National Academy of Food Technologies

Kanatna str., 112, Odesa, Ukraine, 65039

E-mail: anastasiya.orel@ukr.net

ORCID ID: 0000-0001-6575-4370

\title{
SYSTEMATIC APPROACH TO THE ANALYSIS OF RECEIVABLES OF THE ENTERPRISE ON THE BASIS OF STATISTICAL DATA
}

The article examines the economic literature on the approaches to the analysis of receivables of the enterprise. The sequence of receivables analysis has been made by stages: definition of purpose, objects, tasks of analysis, work on sources of information, quantitative and qualitative analysis of receivables, evaluation and generalization of analysis results, development of appropriate recommendations to improve the efficiency of the enterprise. The system of indicators for the qualitative analysis of receivables of the enterprise has been generalized. According to the proposed system of indicators, the relevant calculations were made on the example of the food industry enterprise and recommendations were given to improve the status of settlements with debtors. The analysis carried out in this sequence will allow to assess the real state of receivables of the enterprise, as well as to identify problematic aspects of receivables management, to develop measures to reduce overdue and doubtful receivables.

Key words: receivables, receivables analysis, qualitative analysis, quantitative analysis, coefficients, indicators, financial condition, default risk.

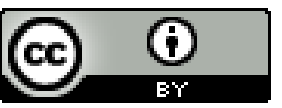

This work is licensed under a Creative Commons Attribution 4.0 International License http://creativecommons.org/licenses/by/4.0/
Statement of the problem and its connection with important scientific and practical tasks. Usually receivables account for a large share of current assets of the enterprise, and therefore has a significant impact on its financial condition.

In a market economy, the presence of a small amount of receivables in the company is acceptable, but a significant increase in the latter can have negative consequences, as buyers will not always be able to fulfill their obligations in full and on time. Therefore, it is important for the company to be able to properly assess the condition and analyze receivables.

To date, the problem of the risk of default by debtors has been significantly complicated by the coronavirus pandemic. Quarantine measures and restrictions have had a significant impact on the financial situation of many businesses, especially small businesses. This problem makes the topic more relevant, because thanks to the proper organization of accounting and analysis of receivables, it is possible to avoid the risks of default and eliminate existing difficulties.

The analysis of the latest publications on the problems. The problem of methods of accounting and analysis of receivables at the enterprise was considered in the works of domestic and foreign scientists in different areas:

- approaches to determining the nature of receivables were covered in the works of M.D. Bilyk, E.A. Ivanov, M.V. Kuzhelny.

- the issues of accounting for settlements with debtors were considered by such specialists as F.F. Butynets, M.S. Pushkar, V.O. Shevchuk, D. Stone, J. Van.Horn, Body Zwi.

- the method of analysis of receivables in modern economic conditions was proposed by such scientists as E.P. Gnatenko, T.C. Yedinak, P.Ya. Popovich, GV Savitska, O.Ya. Bazilinska, V.B. Ivashkevich, O.Г. Lyshchenko, I.I. Pasinovich and others.

As can be seen from the above, the issue of accounting and analysis of receivables has been considered in a large number of papers by various experts, but, despite this, this problem remains relevant today, and therefore needs to be considered in further research.

Forming of the aims of the research. The purpose of the article is to study the economic literature 
on the approaches to the analysis of receivables of the enterprise, as well as conducting qualitative and quantitative analysis of receivables according to the proposed method on the example of the food industry enterprise.

Giving an account of the main results and their substantiation. According to the Regulation (standard) of accounting 10 "Accounts receivable" is the amount of debt of debtors to the company at a certain date [1].

Presence of receivables in the company is a normal phenomenon, but it is important to control its volume, which depends on the terms of settlements with customers, the period of deferred payment, payment discipline of customers, the organization of control over receivables at the company.
The analysis of receivables should be aimed at identifying the factors that affect the state of receivables, namely its growth and the development of measures to prevent this.

Information on the disclosure of receivables of the enterprise is provided in the financial statements, namely in the form №1 "Balance Sheet (Statement of financial condition of the enterprise)" you can find information on long-term receivables and receivables classified by type (lines 1040,1120-1155) and Form №5 "Notes to the annual financial statements" reflects receivables by maturity (lines 940-970).

Today, there are a large number of approaches to the method of analysis of receivables, proposed by scientists in the economic literature, the most common of which are shown in table 1 .

Directions for the analysis of receivables in the economic literature*

\begin{tabular}{|l|l|}
\hline \multicolumn{1}{|c|}{ Author } & \multicolumn{1}{c|}{ Areas of analysis of receivables } \\
\hline F.F. Butynets & $\begin{array}{l}\text { Analysis taking into account the parameters: the time of turnover of receivables, the structure of } \\
\text { debtors on various grounds, schemes of settlements with customers, the scheme of control over } \\
\text { the fulfillment of their obligations by debtors, the principles of provisioning for doubtful debts. }\end{array}$ \\
\hline G.V. Savitskaya & $\begin{array}{l}\text { Analysis of the reasons for the change in receivables. } \\
\text { Assessment of its quality and liquidity. } \\
\text { The speed of collection of receivables. } \\
\text { Losses from its late repayment. }\end{array}$ \\
\hline P.Ya. Popovich & $\begin{array}{l}\text { Analysis of the state of receivables: dynamics, } \\
\text { magnitude, composition and movement. } \\
\text { Doubtful and bad debts are considered. } \\
\text { Accounts payable analysis. }\end{array}$ \\
\hline E.P. Gnatenko & $\begin{array}{l}\text { Analysis of the dynamics, structure by terms and types of occurrence to identify overdue and bad } \\
\text { debts, comparative analysis with accounts payable. }\end{array}$ \\
\hline $\begin{array}{l}\text { Pasinovich I.I., } \\
\text { Shevchuk O.M. }\end{array}$ & $\begin{array}{l}\text { Application of the following indicators for the analysis: the ratio of diversion of working capital } \\
\text { into receivables, the turnover ratio of receivables, the average maturity, the ratio of receivables } \\
\text { and payables. }\end{array}$ \\
\hline
\end{tabular}

* compiled by the authors based on sources [2-6]

Table 1 shows that the approaches of scientists to the analysis of receivables differ. Butynets F.F. considers receivables by characteristics and pays attention to control over the timeliness of repayment of receivables by debtors. Popovich P.Ya. and Gnatenko EP offer to conduct a quantitative analysis of receivables, taking into account the comparative analysis of accounts payable and receivables. In contrast to the above scientists, Pasinovich II and Shevchuk OM offer to calculate indicators that characterize the state of receivables, without paying attention to accounts payable. Savitska GV considers the reasons for the change in receivables, as well as analyzes the risks of late repayment.

Thus, the study of the economic literature allowed us to make a sequence of analysis of receivables by stages, shown in Figure 1, which, in our opinion, is more appropriate.

In accordance with the proposed method, we will analyze receivables on the example of the food industry enterprise.

At the first stage of the analysis of receivables, its purpose, objects, tasks are determined. The purpose is to determine directly the status of settlements with debtors at the enterprise and to make appropriate management decisions to improve the situation. The objects of the analysis are receivables by type (for products, goods, works and services, by calculations, other current receivables, long-term receivables). The tasks of the analysis can be:

- identification of the factors that initiated the debt;

- assessment of the composition, dynamics and structure of receivables; maturity;

- analysis of receivables of the enterprise by

- analysis of the qualitative state of receivables according to the system of indicators;

- making appropriate management decisions to improve the status of settlements with debtors.

At the second stage of the analysis the sources of information are processed, which are the forms of financial statements (form №1 "Balance Sheet (Statement of financial condition of the enterprise)" and form №5 "Notes to the annual financial statements"), various analytical information on receivables, internal reporting . 


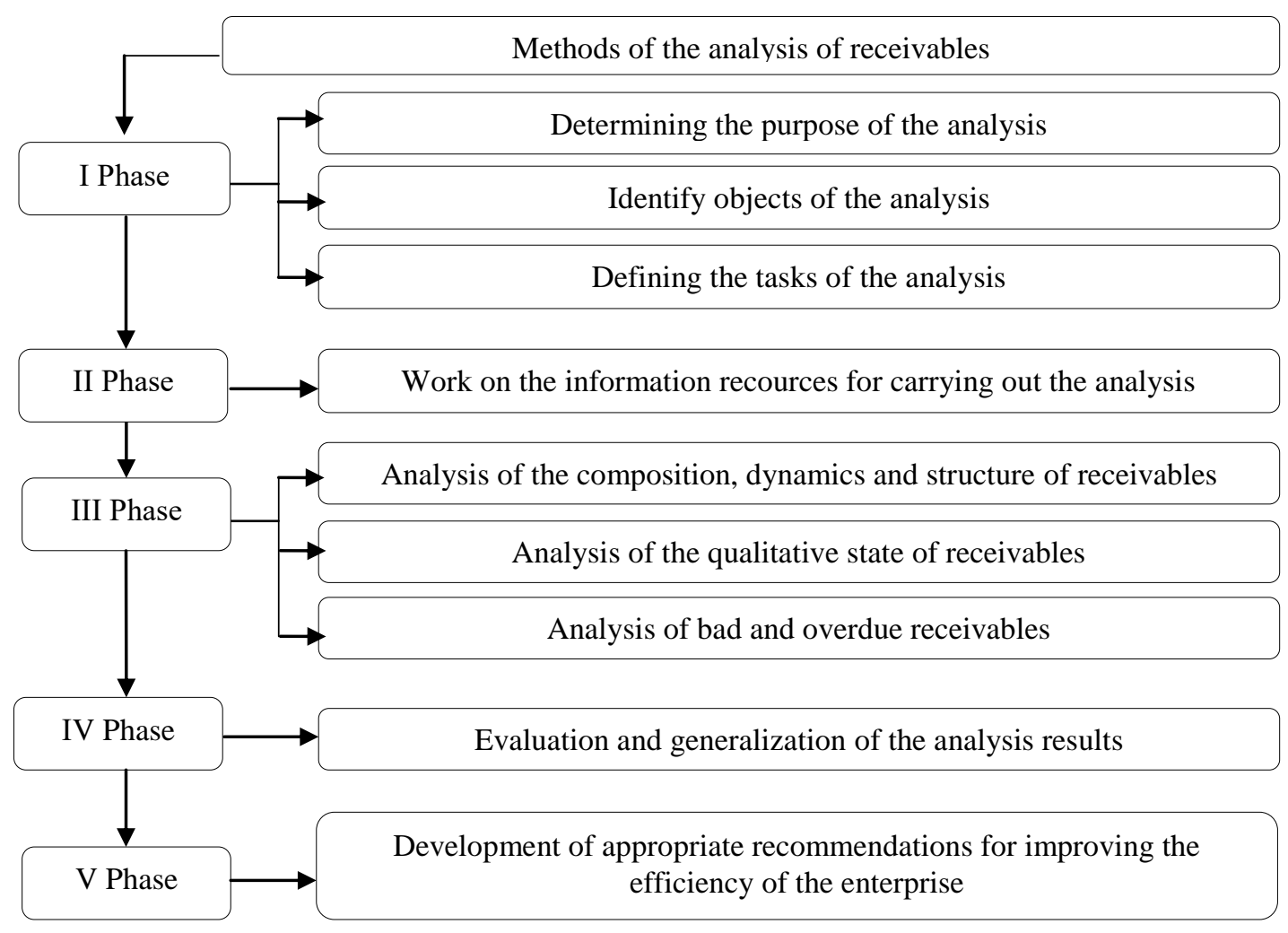

Fig.1. Methods of the analysis of receivables at the enterprise*

*compiled by the authors based on sources [2-4]

At the third stage, the analysis of the composition, dynamics and structure of receivables, usually using an analytical table, table 2 is carried out. At this stage, it is possible to identify at the expense of which types there was a decrease or increase in receivables for a certain period, as well as the share of each type in the total debt.

Next, a system of indicators that characterize the state of receivables is calculated.

Table 2

Analysis of the composition, structure and dynamics of receivables on the example of the food industry enterprise*

\begin{tabular}{|c|c|c|c|c|c|c|c|c|}
\hline \multirow[b]{2}{*}{ Indicators } & \multicolumn{2}{|c|}{ Absolute quantity } & \multicolumn{2}{|c|}{ Specific weight, $\%$} & \multicolumn{4}{|c|}{ Deviation } \\
\hline & 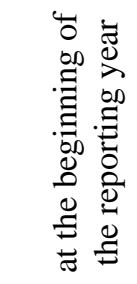 & 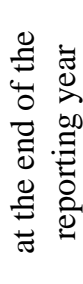 & 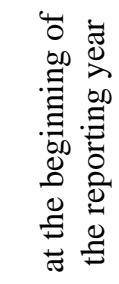 & 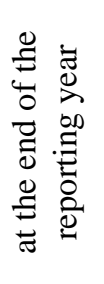 & $\begin{array}{l}\stackrel{0}{\Xi} \\
\stackrel{0}{0} \\
\stackrel{0}{0}\end{array}$ & 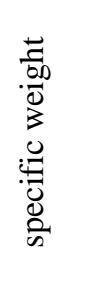 & 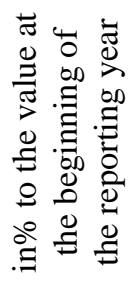 & 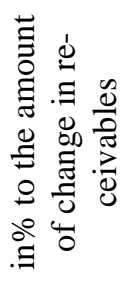 \\
\hline $\begin{array}{l}\text { Accounts receivable total, } \\
\text { including: }\end{array}$ & 5980 & 278 & 100 & 100 & -5702 & $\mathrm{x}$ & $-95,35$ & 100 \\
\hline $\begin{array}{l}\text { 1.1. Accounts receivable for goods, } \\
\text { works, services }\end{array}$ & 1911 & 278 & 31,96 & 100 & -1633 & 68,04 & $-85,45$ & 28,64 \\
\hline \multirow{6}{*}{$\begin{array}{l}\text { 1.2. Accounts receivable according } \\
\text { to calculations: } \\
\text { - for issued advances } \\
\text { - with budget } \\
\text { - including income tax } \\
\text { - from accrued income } \\
\text { - from internal calculations }\end{array}$} & 4069 & - & 68,04 & - & -4069 & $-68,04$ & -100 & 71,36 \\
\hline & 4069 & - & 68,04 & - & -4069 & 68,04 & -100 & 71,36 \\
\hline & - & - & - & - & - & - & - & - \\
\hline & - & - & - & - & - & - & - & - \\
\hline & - & - & - & - & - & - & - & - \\
\hline & - & - & - & - & - & - & - & - \\
\hline 1.3. Other current receivables & - & - & - & - & - & - & - & - \\
\hline
\end{tabular}

* calculated by the authors on the basis of financial statements of the enterprise 
Table 2 shows that receivables at the end of the reporting year compared to the beginning of the year decreased by 5702 thousand UAH or $95,35 \%$. This was due to a reduction in receivables for goods, works and services by UAH $1,633,000$ or by $85,45 \%$, arrears by calculations - by 4069 thousand UAH or $100 \%$. In the structure of receivables at the beginning of the reporting year, the largest share is accounted for by arrears $68, .04 \%$, the share of arrears for goods, works and services amounted to $31, .96 \%$. At the end of the reporting year, the following changes took place in the structure of receivables: the structure of receivables consists entirely of receivables for goods, works and services.

An important aspect of the analysis is the ratio of receivables and payables. This comparison makes it possible to draw certain conclusions about the excess of the former or the latter. Table 3 shows a comparative analysis of receivables and payables on the example of the food industry enterprise.

Table 3

Comparative analysis of receivables and payables on the example of the food industry enterprise*

\begin{tabular}{|c|c|c|c|c|}
\hline \multirow[t]{2}{*}{ Indicators } & \multirow{2}{*}{$\begin{array}{c}\text { Accounts } \\
\text { receivable, } \\
\text { thousand UAH }\end{array}$} & \multirow{2}{*}{$\begin{array}{l}\text { Accounts payable, } \\
\text { thousand UAH }\end{array}$} & \multicolumn{2}{|c|}{ Excess of debt } \\
\hline & & & $\begin{array}{l}\text { accounts } \\
\text { receivable }\end{array}$ & $\begin{array}{l}\text { accounts } \\
\text { payable }\end{array}$ \\
\hline $\begin{array}{l}\text { 1. Debt for goods, works, services, thou- } \\
\text { sand UAH }\end{array}$ & 278 & 10381 & - & 10103 \\
\hline 2. According to calculations: & - & 5368 & - & 5368 \\
\hline - with budget & - & 4630 & - & 4630 \\
\hline - from insurance & - & 27 & - & 27 \\
\hline - on wages & - & 711 & - & 711 \\
\hline 3. Other types of debt & - & 5064 & - & 5064 \\
\hline Total & 278 & 20813 & - & 20535 \\
\hline
\end{tabular}

*calculated by the authors on the basis of the financial statements

Table 3 shows that at the end of the reporting year there was an excess of accounts payable over receivables by 20,535 thousand UAH. This was due to the excess of accounts payable for goods, works and services by UAH 10,103 thousand, arrears by calculations by UAH 5,368 thousand. and other current debt by UAH 5064 thousand. A significant excess of accounts payable over receivables poses a threat to the financial stability of the enterprise.
For effective management of the business entity, it is necessary not only to carry out a quantitative analysis of indicators of current condition, but also to apply a qualitative analysis of receivables, which is the most important stage of the methodology of its analysis. Table 4 shows a system of indicators on which it is advisable to assess the status and qualitative analysis of receivables.

System of indicators characterizing the state of receivables*

\begin{tabular}{|l|l|l|}
\hline \multicolumn{1}{|c|}{ Indicator } & \multicolumn{1}{|c|}{ Calculation formula } & \multicolumn{1}{c|}{ Economic content } \\
\hline $\begin{array}{l}\text { 1. The turnover ratio } \\
\text { of receivables }\end{array}$ & $\begin{array}{l}\text { Rtr = net profit from sales / } \\
\text { average value of receivables }\end{array}$ & $\begin{array}{l}\text { Shows how many times during the period under review, } \\
\text { the funds invested in the calculations circulate. The posi- } \\
\text { tive dynamics of this indicator means the stability of fi- } \\
\text { nancial relations with debtors. }\end{array}$ \\
\hline $\begin{array}{l}\text { 2. The duration of } \\
\text { the receivables re- } \\
\text { payment period }\end{array}$ & $\begin{array}{l}\text { Drrp = reporting period in } \\
\text { days / the turnover ratio of } \\
\text { receivables }\end{array}$ & $\begin{array}{l}\text { Shows how many days it takes the company to receive } \\
\text { payment from buyers (customers) for the work (services } \\
\text { provided). The longer the repayment period, the higher the } \\
\text { risk of debt default. }\end{array}$ \\
\hline $\begin{array}{l}\text { 3. The share of } \\
\text { receivables in total } \\
\text { current assets }\end{array}$ & $\begin{array}{l}\text { SHr = average value of the } \\
\text { receivables / current assets } * \\
100 \%\end{array}$ & $\begin{array}{l}\text { Shows the share of receivables in total current assets. The } \\
\text { value of this indicator determines the mobility of the prop- } \\
\text { erty structure of the enterprise. }\end{array}$ \\
\hline $\begin{array}{l}\text { 4. The ratio of re- } \\
\text { ceivables and paya- } \\
\text { bles }\end{array}$ & Rrp = receivables / payables \\
\hline $\begin{array}{l}\text { 5. The share of } \\
\text { doubtful accounts } \\
\text { receivable in receiv- } \\
\text { ables }\end{array}$ & $\begin{array}{l}\text { SHr = doubtful accounts re- } \\
\text { ceivables / average value of } \\
\text { the receivables } * 100 \%\end{array}$ & $\begin{array}{l}\text { The positive dynamics of this indicator and the amount of } \\
\text { toubtful accounts receivables is a negative trend in set- } \\
\text { tlements with buyers and customers. }\end{array}$ \\
\hline
\end{tabular}
* compiled by authors based on sources [5-7]

Table 4 shows the indicators for a qualitative analysis of receivables. According to these indicators, it is more appropriate to conduct the analysis in dynamics, comparing the calculated indicators for the previous and 
reporting periods. At comparison it is possible to draw conclusions about improvement or on the contrary deterioration of a condition of calculations with debtors.

The fourth and fifth stages are final and summary. At this stage, we evaluate the results of the analysis and draw appropriate conclusions that will further be able to make effective management decisions to improve the state of receivables and the enterprise as a whole.

Accordingly, the indicators presented in table 4 will analyze receivables on the example of the food industry enterprise.

Table 5

Calculation of indicators characterizing the state of receivables on the example of the food industry enterprise*

\begin{tabular}{|c|c|c|}
\hline Indicator & Previous year & Reporting year \\
\hline 1. Net profit, thousand UAH & 11075 & 3178 \\
\hline 2. The average amount of receivables, thousand UAH & 10135 & 3129 \\
\hline 3. Receivables turnover ratio, thousand UAH & 1,09 & 1,02 \\
\hline 4. Duration of the period, days & 360 & 360 \\
\hline 5. Duration of the receivables repayment period, days & 330 & 353 \\
\hline 6. The value of current assets, thousand UAH & 20170 & 16182 \\
\hline 7. The share of receivables in total current assets, $\%$ & 50,25 & 19,34 \\
\hline 8. The amount of accounts payable, thousand UAH & 20216 & 15479 \\
\hline 9. The ratio of receivables and payables & 0,3 & 0,02 \\
\hline
\end{tabular}

* calculated by the authors on the basis of financial statements of the enterprise

Table 5 shows that in the reporting year compared to the previous year, the turnover ratio of receivables decreased significantly, which negatively characterizes the activities of the enterprise. The length of the receivables repayment period increased significantly from 330 days to 353 days, which indicates a higher risk of non-repayment of debts. The ratio of receivables and payables showed that the company is not able to pay its debts to creditors at the expense of receivables.

Thus, the analysis of receivables showed what exactly the management of the company should pay attention to in order to eliminate the shortcomings associated with receivables. The analysis of the composition, structure and dynamics of assets showed that receivables at the end of the reporting year compared to the beginning of the year decreased by 5702 thousand $\mathrm{UAH}$ or $95,35 \%$. In the structure of receivables at the beginning of the reporting year, the largest share is accounted for by arrears $-68,04 \%$, the share of arrears for goods, works and services amounted to 31,96\%. At the end of the reporting year, the following changes took place in the structure of receivables: the structure of receivables consists entirely of receivables for goods, works and services. A comparative analysis of receivables and payables showed that at the end of the reporting year there was an excess of accounts payable over receivables by 20,535 thousand UAH. This was due to the excess of accounts payable for goods, works and services by UAH 10,103 thousand, arrears by calculations by UAH 5,368 thousand. and other current debt by UAH 5064 thousand. Qualitative analysis showed that the turnover ratio of receivables has decreased significantly, which negatively characterizes the activities of the enterprise. The length of the receivables repayment period increased significantly from 330 days to 353 days, which indicates a higher risk of non-repayment of debts. The ratio of receivables and payables showed that the company is not able to pay its debts to creditors at the expense of receivables.

In our opinion, the analysis of receivables according to the proposed method is optimal. It will provide an opportunity to assess the real state of receivables of the enterprise, as well as to identify problematic aspects and nuances of receivables management, to develop measures to reduce overdue and doubtful receivables.

The proposed method can be used to identify and eliminate deficiencies related to receivables in order to improve the efficiency of the enterprise.

Conclusions and prospects of the further investigations. Thus, the article considered the most common approaches to the analysis of receivables in the economic literature, proposed stages of the analysis of receivables, which include: definition of purpose, objects, tasks of analysis, work on sources of information, quantitative and qualitative analysis of receivables, evaluation and generalization of the results of the analysis, development of appropriate recommendations to improve the efficiency of the enterprise. According to these stages, the analysis of receivables was carried out on the example of the food industry enterprise. The proposed method will allow you to properly organize the analysis of receivables, as well as timely identify problems of occurrence and prevention of overdue receivables, which will increase the efficiency of economic activity of the enterprise and reduce the risk of default. 


\section{References}

1. Debitorska zaborhovanist: Polozhennia (standart) bukhhalterskoho obliku 10, zatv. Nakazom Ministerstva finansiv Ukrainy vid 08.10.1999 r. № 237 za stanom na 27.06.2013. Retrieved June 1, 2020, from http://zakon.rada.gov.ua/laws/show/z0725-99

2. Butynets, F. F. (2009). Bukhhalterskyi finansovyi oblik. Zhytomyr: PP «Ruta».

3. Savytska, H. V. (2015). Ekonomichnyi analiz diialnosti pidpryiemstva: navchalnyi posibnyk. Kyiv: Znan-

nia.

4. Hnatenko, Ye. P., \& Lebedyk, A. M. (2016). Suchasni metodyky analizu debitorskoi zaborhovanosti. Molodyi vchenyi, (11), 562-565. Retrieved June 1, 2020, from http://nbuv.gov.ua/UJRN/molv_2016_11_132

5. Pasinovych, I. I., \& Shevchuk, O. M. (2013). Aktualni problemy analizu i upravlinnia debitorskoiu zaborhovanistiu pidpryiemstva. Ekonomika. Upravlinnia. Innovatsii, (2). Retrieved June 1, 2020, from http://nbuv.gov.ua/UJRN/eui_2013_2_65

6. Savitskaya, G. V. (2019). Analiz effektivnosti i riskov predprinimatelskoy deyatelnosti: metodologicheskie aspektyi (2nd ed., pererob. i dop.). Moscow: INFRA-M. Retrieved June 1, 2020, from www.dx.doi.org/10.12737/23374

7. Mishchuk, Ye. V., \& Sydorova, I. I. (2018). Analiz debitorskoi ta kredytorskoi zaborhovanosti: problemni aspekty. Ekonomichna nauka, (2), 54-57. Retrieved June 1, 2020, from http://www.investplan.com.ua/pdf/2_2018/12. pdf

8. Lysenko, A. M. (2014). Metodyka provedennia analizu debitorskoi zaborhovanosti sub'iektiv hospodariuvannia. Ekonomichni nauky, (26), 184-192. Retrieved June 1, 2020, from http://dspace.kntu.kr.ua/jspui/bitstream/123456789/291/1/28.pdf

9. Antoniuk, O. P., Stupnytska, T. M., \& Kuprina, N. M. (2015). Ekonomichnyi analiz. Lviv: Mahnoliia 2006.

10. Stupnytska T., Volodina O., Holovachenko L., \& Vasylieva, Yu. (2018). Methods of the analysis of the debts receivable: Modern aspect. Food Industry Economics. 10(3), 94-101. doi: 10.15673/fie.v10i3.1066

Received 20 June 2020

Approved 4 July 2020

Available in Internet 15.10.2020

Ступницкая Т.M.

кандидат экономических наук, доцент кафедра учета и аудита

E-mail: t.stupnitska@gmail.com

ORCID ID: 0000-0002-2517-2795

\section{Володина Е.П.} ассистент

кафредра иностранных языков

E-mail: volodinaolenaonaft@gmail.com

ORCID ID: 0000-0003-0552-6733

\author{
Антонюк О.П. \\ кандидат экономических наук, доцент \\ кафедра учета и аудита \\ E-mail: olegantoni@ukr.net \\ ORCID ID: 0000-0002-9182-4982
}

\section{Орел А.C.}

магистрант

кафедра учета и аудита

Одесская национальная академия пищевых технологий ул. Канатная, 112, г. Одеса, Украина, 65039

E-mail: anastasiya.orel@ukr.net

ORCID ID: 0000-0001-6575-4370

\section{СИСТЕМНЫЙ ПОДХОД К АНАЛИЗУ ДЕБИТОРСКОЙ ЗАДОЛЖЕННОСТИ ПРЕДПРИЯТИЯ НА ОСНОВЕ СТАТИСТИЧЕСКИХ ДАННЫХ}

Организация учета дебиторской задолженности имеет важное значение для субъектов хозяйствования всех отраслей. Успешное функционирование любого предприятия возможно при условии правильной организации управления расчетов с дебиторами. Стратегическое значение данной проблемы заключается в том, что дебиторская задолженность оказывает влияние на ликвидность активов, финансовое состояние и платежеспособность предприятия.

В статье проведен анализ экономической литературы по вопросам подходов к анализу дебиторской задолженности предприятия. Приведена последовательность проведения анализа дебиторской задолженности по этапам: определение цели, объектов, задач анализа; работа над источниками инфоромации; проведение количественного и качественного анализа дебиторской задолженности; оценка и обобщение результатов анализа; разработка соответствующих рекомендаций по повышению эффективности деятельности предприятия. Обобщена система качественных показателей для анализа дебиторской задолженности предприятия, к которым можно отнести: коэффрициент оборачиваемости дебиторской задолженности, продолжительность периода ее погашения, доля дебиторской 
задолженности в общем объеме оборотных активов, коэффрициент соотношения дебиторской и кредиторской задолженности. По предложенной системе показателей были проведены расчеты на примере предприятия пищевой промышленности и даны рекомендации по улучшению расчетов с дебиторами. Анализ, проведенный по предложенной последовательности, позволит оценить реальное состояние дебиторской задолженности предприятия, а также выявить проблемные аспекты по управлению дебиторской задолженностью, разработать меры по сокращению просроченной и сомнительной дебиторской задолженности.

Ключевые слова: дебиторская задолженность, анализ дебиторской задолженности, управление дебиторской задолженностью, качественный анализ, количественный анализ, коэффрициенты, показатели, финансовое состояние, риск неплатежей.

Ступницька Т.M.

кандидат економічних наук, доцент кафедра обліку та аудиту

E-mail: t.stupnitska@gmail.com

ORCID ID: 0000-0002-2517-2795

\section{Володіна О.П.} асистент

кафредра іноземних мов

E-mail: volodinaolenaonaft@gmail.com ORCID ID: 0000-0003-0552-6733
Антонюк О.П.

кандидат економічних наук, доцент кафедра обліку та аудиту E-mail: olegantoni@ukr.net ORCID ID: 0000-0002-9182-4982

\section{Орел А.C.}

магістрант кафедра обліку та аудиту

Одеська національна академія харчових технологій вул. Канатна 112, м. Одеса, Україна, 65039

E-mail: anastasiya.orel@ukr.net ORCID ID: 0000-0001-6575-4370

\section{СИСТЕМНИЙ ПІДХІД ЩОДО ЗДІЙСНЕННЯ АНАЛІЗУ ДЕБІТОРСЬКОЇ ЗАБОРГОВАНОСТІ ПІДПРИЄМСТВА НА ПІДСТАВІ СТАТИСТИЧНИХ ДАНИХ}

Організація обліку дебіторської заборгованості має важливе значення для суб'єктів господарювання усіх галузей. Адже успішне функціонування будь-якого підприємства можливе за умови правильної організації управління розрахунками з дебіторами. Стратегічне значення даної проблеми полягає в тому, що дебіторська заборгованість здатна впливати на ліквідність активів, фінансовий стан та платоспроможність підприємства.

В статті проведено дослідження економічної літератури з питань розгляду підходів до аналізу дебіторської заборгованості підприємства. Складено послідовність проведення аналізу дебіторської заборгованості за етапами: визначення мети, об'єктів, завдань аналізу; робота над джерелами інфоромації; проведення кількісного та якісного аналізу дебіторської заборгованості; оцінка та узагальнення результатів аналізу; розробка відповідних рекомендацій щодо підвищення ефективності діяльності підприємства. Узагальнено систему показників для якісного аналізу дебіторської заборгованості підприємства, до яких можна віднести: коефіцієнт оборотності дебіторської заборгованості, тривалість періоду погашення, питома вага дебіторської заборгованості в загальному обсязі оборотних активів, коефіцієнт співвідношення дебіторської та кредиторської заборгованості. За запропонованою системою показників були проведені відповідні розрахунки на прикладі підприємства харчової промисловості та надані рекомендації щодо покращення стану розрахунків з дебіторами. Аналіз, проведенний за розглінутою послідовністю надасть змогу оцінити реальний стан дебіторської заборгованості підприємства, а також дозволить виявити проблемні аспекти щодо управління дебіторською заборгованістю, розробити заходи щодо скорочення простроченої та сумнівної дебіторської заборгованості.

Ключові слова: дебіторська заборгованість, аналіз дебіторської забогованості, управіління дебіторською забогованістю, якісний аналіз, кількісний аналіз, коефріцієнти, фінансовий стан, ризик неплатежів. 


\section{Література}

1. Дебіторська заборгованість: Положення (стандарт) бухгалтерського обліку 10, затв. Наказом Міністерства фінансів України від 08.10.1999 р. № 237 за станом на 27.06.2013. URL: http://zakon.rada.gov.ua/laws/show/z0725-99 (дата звернення: 01.06.2020p.).

2. Бухгалтерський фінансовий облік: підручник для студентів спеціальності «Облік і аудит» вищих навчальних закладів / Ф. Ф. Бутинець та ін. Житомир: ПП «Рута», 2009. 912 с. 2015. 662 c.

3. Савицька Г.В. Економічний аналіз діяльності підприємства: навчальний посібник. Київ: Знання,

4. Гнатенко Є. П. Сучасні методики аналізу дебіторської заборгованості / Є. П. Гнатенко, А. М. Лебедик // Молодий вчений. 2016. № 11. С. 562-565. - URL: http://nbuv.gov.ua/UJRN/molv_2016_11_132. (дата 3вернення: 01.06.2020).

5. Пасінович I.І., Шевчук О.М. Актуальні проблеми аналізу і управління дебіторською заборгованістю підприємства // Економіка. Управління. Інновації. 2013. № 2. URL: http://nbuv.gov.ua/UJRN/eui_2013_2_65. (дата звернення: 01.06.2020).

6. Савицкая Г.В. Анализ эффективности и рисков предпринимательской деятельности: методологические аспекты: монография. 2-е изд., перераб. и доп. М.: ИНФРА-M, 2019.291 c. URL: www.dx.doi.org/10.12737/23374 (дата звернення: 01.06.2020).

7. Міщук Є.В., Сидорова I.І. Аналіз дебіторської та кредиторської заборгованості: проблемні аспекти // Економічна наука. 2018. № 2. С. 54-57. Режим доступу: http://www.investplan.com.ua/pdf/2_2018/12. pdf (дата звернення: 01.06.2020).

8. Лисенко А.М. Методика проведення аналізу дебіторської заборгованості суб'єктів господарювання // Економічні науки. 2014 № 26. C. 184-192. URL: http://dspace.kntu.kr.ua/jspui/bitstream/123456789/291/1/28.pdf (дата звернення: 01.06.2020).

9. Антонюк О.П., Ступницька Т.М., Купріна Н.М. Економічний аналіз: практикум: навч. посібник. Львів: Магнолія-2006, 2015. 325 с.

10. Stupnytska T., Volodina O., Holovachenko L., Vasylieva Yu. Methods of the analysis of the debts receivable: Modern aspect // Food Industry Economics. 2018. Vol.10, Issue 3. P. 94-101. doi: 10.15673/fie.v10i3.1066

Стаття надійшла 20.06.2020

Стаття прийнята до друку 4.07.2020

Доступно в мережі Internet 15.10.2020

Цитування згідно ДСТУ 8302:2015

Stupnytska T., Antonyuk O., Volodina O., Orel A. Systematic approach to the analysis of receivables of the enterprise on the basis of statistical data // Food Industry Economics. 2020. Vol.12, issue 3. P. 25-32. doi: 10.15673/fie.v12i3.1813

Cite as APA style citation

Stupnytska, T., Antonyuk, O., Volodina, O., \& Orel, A. (2020). Systematic approach to the analysis of receivables of the enterprise on the basis of statistical data. Food Industry Economics, 12(3), 25-32. doi: 10.15673/fie.v12i3.1813 